\title{
Sexual Education in Khazanah Fiqh Pesantren (Islamic Jurisprudence)
}

\author{
${ }^{1 *}$ Muchamad Mufid, ${ }^{2}$ Herlina \\ ${ }^{1,2}$ Faculty of Tarbiyah and Teaching Science, UIN Sunan Kalijaga Yogyakarta \\ mufid.fantascience4@gmail.com \\ ellynmustafa31@gmail.com
}

\begin{abstract}
Some people still think that sexual education is forbidden things and unnecessary, because they assume that sexual education only teaches sex between men and women. Whereas sexual education is not just about sex but gives lessons about sexual development, reproductive health, and social relationships. In khazanah Fiqh pesantren has explained both sexually explicit and implicit sexual education. This research is a kind of literature research by seeking sexual education in fiqh books often studied in pesantren (Islamic Boarding schools). As a result, in khazanah Fiqh pesantren sexual education in general is divided into two parts. The first part, discussed about thaharah (purification), covering aurat, signs of puberty, and related to women Fiqh such as menstruation, childbirth, or wiladah. In the second part discussed from marriage, the importance of marriage, manners, and so on to establish a harmonious psychological relationship between husband and wife.
\end{abstract}

Keywords: Sexual Education; Fiqh; Pesantren

\section{Research Background}

Many people who prejudice sex education as providing information about reproduction and sexual relations. Sex education is actually not just that. Haffner (1990) states that comprehensive sexuality education covers biological, sociocultural, psychological, and spiritual dimensions including teaching someone to be self-protective and responsible (Zarina and Felianti, 2012).

In addition, during this time there was also a mistaken view among Muslims who considered sexuality as taboos and did not need to be discussed at length. This view is denied by Yusuf Qardhawi. He acknowledged that the books of tafsir, hadiths, figh, literature, and so forth, many talks about sexuality issues. Even still Qardhawi, not even a Muslim scholar who forbids this talk during the course of science and lessons (Moqsit, 2002).
As a social being, humans cannot avoid associations of others. He has the freedom to mingle and enters a diverse community of diverse backgrounds. But freedom is not always absolute. Of course, there are certain limits that are normatively approved by the community as well as religious teachings that he believes is true. Without that limitation, he would lose his perfection and glory, as he would be trapped in moral impairment which would impossibly damage his soul (Sahal, 97).

Islam as a universal religion has given the guidance of life for man, as well as being the difference between the right and the wrong (Al-Baqarah: 185). All aspects of life have clear guidance both explicitly and implicitly. From small things like purification (hygiene), to great things like leadership in state affairs. Likewise, in Islam it is discussed about 
sexuality from childhood to matters relating to husband and wife.

In Islamic tradition, Fiqh has a central role as a legal instrument to regulate the lives of Muslim societies. They need legal tools whose characters are not purely normative textual (Qur'an and Hadith), but have been structured into a lawful application of Fiqh. Therefore, Fiqh is codified to manage the entire operational activities of human beings, ranging from religious ritual to profane, political, social, economic, and cultural issues (Thoha, 2004).

Pesantren is Indonesia's original Islamic educational institution, which is currently a legacy of Indonesian wealth that continues to grow. Even when entering this third millennium becomes one of the most important buffs for the nation and state of Indonesia (Zamakhsyari, 2015). Usually every pesantren gives figh material that includes ritual procedures to the way of life, even arrange until the smallest, such as manners in the toilet or sexual morality. About sexuality, in the study of the fiqh has been discussed extensively from the signs of puberty to how to have a good husband and wife.

Therefore, the writer is interested to present the writings of "sexual education in khazanah figh pesantren."

\section{Method}

In this study, researchers used library research, namely research by studying and reading (Sanjaya, 2013). Each study requires materials sourced from the library, including books, magazines, and other documentary materials (Nasution, 2012). Library research is intended to obtain complete information, and to determine the actions to be taken as important steps in scientific activities (Subagoyo, 2006).

In literature study there are at least four main characteristics that researchers need to pay attention to, among them: First, that the writer or researcher is dealing directly with text (nash) or numerical data, not directly with knowledge from the field. Second, the library data is "ready to use" meaning that the researcher is not directly spacious because the researcher is dealing directly with the data sources in the library. Third, that library data is generally a secondary source, in the sense that researchers obtain material or data from the second hand rather than the original data from the first data in the field. Fourth, that the condition of library data is not limited by space and time (Mestika, 2003).

So, in this study, researchers discussed sexual education found in khazanah Fiqh pesantren. The source of the literature is found in the books of Fiqh which are often referred to by Pesantren both in routine recitation and bahtsul masail activities.

\section{Sexual Education}

Sexual education is a lifelong process of obtaining information and forming behaviors, beliefs, values about identity, relationships and intimacy. Sexual education deals with sexual development, reproductive health, interpersonal relationships, feelings (affection), intimacy, body concepts and gender roles. Sexual education deals with the biological, sociocultural, psychological and spiritual aspects of three domains, namely cognitive, affective, and behavioral including the ability to communicate effectively and make responsible decisions (Nur Mahmudah, 2015). 
Sexuality is an urgent study to be introduced to children. Therefore, Alya Andika informs in her book entitled Talking Together Sex with Children, talking that she deserves special attention with the aim of minimizing the emergence of errors due to misunderstanding of definitions or can also fix children's mind set about sexuality (Alya Andika, 2010). The same thing was agreed by Madani by giving the meaning of sex education which was not much different from the previous opinion, namely an effort to provide knowledge about sex in order to prepare it to be able to interact well with its environment (Alya Andika, 2010).

Furthermore, sexual teaching can begin when a child is 5 years old (Nicole Haberland and Deborah Rogow, 2015). Important early knowledge is given so that they recognize and know the functions of their vital organs so that they can guard them from bad behavior. Today, parents give positive feedback if sex education is implemented in schools. it means the introduction of education for sex is not only applied by the family but also by the teacher and others (Salmi Ahmad Sudan, 2015).

The steps to provide sexual education that can be carried out have several characteristics for the effectiveness of sex education in children, including:

1) Focuses on Specific behavioral outcomes

2) Addresses individual values and group norms that support healthenhancing behaviors.

3) Focuses on increasing personal perceptions of risk and harmfulness of engaging in specific health risk behaviors, as well as reinforcing protective factors.

4) Addresses social pressures and influences
5) Build personal and social competence.

6) Provides functional knowledge thas is basic, accurate and directly contributes to health promoting decisions and behaviors.

7) Uses strategies designed to personalize information and engage student

8) Provides age-and developmentallyappropriate information, learning strategies, teaching method and materials.

9) Incorporates learning strategies, teaching methods and materials that are culturally inclusive.

10) Provides adequate time for instruction and learning.

11) Provides opportunities to reinforce skills and positive health behaviors.

12) Provides opportunities to make connections with other influential persons.

13) Includes teacher information and plan for professional development and training to enhance effectiveness of instruction and student learning (2007).

From these characteristics, there is also a standard for providing knowledge in providing an understanding of sex education. The key points in the Sex Education Standard concept include:

1) Personalization

2) Susceptibility

3) Self-Efficafy

4) Social Norms

5) Skills (2007).

The results of the research presented by Leafio Rinta reveal how sexual education is for adolescents. The results of his research show that sexual education has a positive impact on the psychological resilience of adolescents, 
namely the creation of teenagers who have positive sexual behavior. Psychological resistance in question can be known as its characteristics, namely:

1) Having sufficient knowledge about sexual education.

2) Able to protect themselves and control themselves from negative behaviors.

3) Able to solve problems, have initiative, empathy, and self-efficacy.

4) Having the desire to prepare for the future (Leafio Rinta, 2015).

The discussion of sexuality from generation to generation should be the main focus in education. Today, young people need to be provided with sexual education in order to create strong control. If the news is often found criminal cases committed by young women, from that it should be used as an urgent record of sexuality to be applied in various institutions both private and public schools.

\section{Fiqh Pesantren}

Fiqh is one of Islamic scientific branch that usually is the most important considered. Cause Figh has various concrete implication for person or majority. Fiqh teached to the moslim people about somethings like a behavior are forbidden and recommended. However, whether we look the Islamic history of Indonesia, essence of the Fiqh it seems like not stronger rather than this era. At first, Islam in Indonesia is very oriented for Tasawuf, and by gradually, that is being more oriented for Syariah (Bruinessen, 2015). That is, surely rather not make a confuse, because the spreading of Islam on the first periode is implemented for Arab people that is planted and more relate to the Taubid and akblak, which interesting to the Tasawnf. The problem is appearing to the Nabi
Muhammad dakwah, on Mekekah Periode. It was only later that Muslim were gradually taught about worship in Madina (Aksin, 2016). Therefore, the obligations and rules as a servant of Allah, and worshid with full happiness.

In Pesantren itself, Fiqh is the most important scientific branch because its roles very intensive as a basic in daily religious practice. This branch is very determining for the type of pesantren later, namely: as an adherent of figh madrhabi. With that comprehense, Pesantren have made to build of fanaticism on be a marbab, especially madzhab Syafi'i. in Pesantren, this comprehense is being a culture, and being ideology, until to their kitab then known a al-kutub al-mu'tabarah, namely te most autorithative kitab, Selective, recognized to use istinbath al-abkam activities in Pesantren area, include NU (Rijal, 2015).

Scientific texts of Pesantren (Islamic boarding school) are closer to Fiqh (syariah or Islamic law) which appear normative rather than the other, such as interpretation, Sufism, and theology, and ushul Fiqh. Fiqh is one of the most interesting subjet for santri (Student). That's all seem clearly from the term of ulama who study deeply (Yazid, 2018).

This is rather not surprising because the influence of Imam AzZarnuji's thought on his Kitab namely Ta'lim al-Muta'alli that is being basis of educational pesantren's thought. he recommends to study Fiqh science which show up to the kindness and piety. The Fiqh Science is science that show seeral guidance ways and survivable self to another one's. indeed, those who are Figh more feared by Devil rather than a thousand people who are worshiper's expert. 
The Fiqh KItab in Pesantren is more often read to bandongan or marathon system; a teacher reads the book lafdhan wa maknan (text and meaning), while the santri write down the meaning given complete with their position in the structure of the Arabic grammar (nahwu and sharaf) and the marks of each position (as mubtada ', khabar, maf ul, badal, and so on). Rarely does the yellow book study in pesantren use the method of discussion (Yazid, 2018).

The most popular works of jurisprudence include Taqrib (Al-Ghayah wa Al-Taqrib, which is also famous for Mukhtashar, by Abu Syuja 'Al-Isfahani) and the direction of Fathul Qarib (by Ibn Qasim Al-Ghazzi). Almost no pesantren does not use at least one of these texts (Bruinessen, 2015). In addition, the book Safinah an-Najah (with Syarahnya Kasyfiyatu al-Saja), and Kifayatul Akhyar. The book of Islamic Fiqh wa Adilatuhu is also often used as a reference in bahtsul masail, although this book is not taught in recitation.

The most popular Figh namely Taqrib (Al-Ghayah wa Al-Taqrib, which is also famous for Mukhtashar, by Abu Syuja 'Al-Isfahani) and the direction of Fathul Qarib (by Ibn Qasim Al-Ghazzi). Almost no pesantren does not use at least one of these texts (Bruinessen, 2015). In addition, the book of Safinah an-Najah (with the Syarah Kasyfiyatu al-Saja), and Kifayatul Akbyar. The book of Figh wa Adilatubu is also often used as a reference in babtsul masail, although this book is not taught in recitation.

The classic book that talks about sex in Islam is Uqud Al-Luja'in and Qurratul Uyun. Both are generally studied in traditional Islamic boarding schools (Pesantren). In Indonesia the classic book (kitab) Uqud Al-Lujain by Imam Nawawi
al-Bantani is a study material to see the relations of men and women are more equitable (Nurcholish, 2015). The Qurratul Uyun is a classic book (Kitab) of shura (explanatory) of Nazham Ibn Yamun that written by Abi Muhammad Sayid Qasim bin Ahmad ibn Musa ibn Yamun. The classis book (kitab) is about shari'a marriage, sunnah marriage, and fun things in marriage. Both of books are usually not included in the curriculum of pesantren, but are taught during the month of Ramadan which is usually referred to as recitation of posoan by reciting it during a month.

\section{Sexual Education in Fiqh Pesantren}

Sexuality education in the jurisprudence of Islamic Figh is divided into two parts, namely: first, discussing the sign for children who are considered capable of carrying out religious order (taklif), menstruation problems, childbirth, istikhadhah for women, something that require to take a bath, circumcision, ibtilam (wet dream) and a number of other one's (Mahmudah, 2015). Although since childhood, the Islamic jurisprudence books (Fiqh Pesantren) have discussed about thaharah (purity) after urinating or defecating. This is certainly related to maintaining health while maintaining the sanctity of the body. Second, talking about sex in the context of reproduction of the next generation of Muslims both related to marriage, husband and wife relations, something that need to be considered in connection and also the psychological relationship between husband and wife.

\subsection{The First}

\subsubsection{Purify}

Everyone, in an overnight is always removes dirt with various forms such as 
urine and feces. In a day, humans can excrete several times, such as urinating that is not possible only once a day. Although in the beginning the impurities were contained in the human body, but after leaving it became a filth and unclean in the view of Shari'a. Therefore, people need to clean the excretion site in a manner determined by Shari'a.

In Fathul Qarib's book (kitab), when a person is both a child and an adult to urinate or defecate, it is obligatory to purify. The way to purify is regulated by using water or holy stones to purify, or both of them (al-Ghazi, 2016). This indicates that Islamic jurisprudence (Fiqh Pesantren) is very concerned about the cleanliness of the body to Muslims with almost all fiqh books (kitab Fiqh) putting the chapter of thaharah (purify) at the beginning of the study. Especially on genital hygiene that is used as a place of unclean discharge.

In Islamic boarding school jurisprudence (Figh Pesantren) not only pay attention in terms of physical cleanliness, but spiritual cleanliness. Not surprising because in humans, in addition to physical elements, there are also elements of reason, and spirituality. This can be seen clearly in the provision of recommended prayers. Starting from entering the toilet, after washing, until it comes out of the toilet. Provisions when in the toilet are also discussed properly, such as prohibited from mentioning names of Allah SWT verbally or mentally (with excessive).

Since childhood/baby a child should be trained to maintain cleanliness of the body. Because the baby cannot clean the dirt or impurities that are on him, the parents must immediately clean. With habituation, when you can do it independently, it is expected that a child will always maintain the cleanliness of himself both physically and mentally. If not trained like that, it could be that a child would be careless about their hygiene, or even not purify after urinating.

\subsubsection{Close the Genitals (Aurat)}

Islam is also requiring the people to close or cover their genitals for each and every male and female. Aurat is a part of a person's body that must be covered and not seen by others. Especially on body parts related to reproduction. Even to same sex, there are limitations that are private in nature that cannot be seen. This indicates that in the human body there are parts that need to be guarded and become his personal secret. This must be accustomed to someone from an early age.

Closing the genitals (aurat) in the information technology era is not only done in the real world, but also in cyberspace (social media). It is undeniable that people active on social media such as Facebook, Twitter, Instagram, WhatsApp, Telegram and etc. Even a person has all the social media accounts and often in a day uploadable several photos. In these circumstances a person have to close his genitals because many people also see their self or aurat.

Sheikh Wahbah Zuhaili defines the aurat according to syara' is something that must be hidden and forbidden to see it. In opinion of the scholars number, those who pray are required to close their genitals, whether they are able to do so, even if the prayer is done alone in a dark place. When performing prayers, a person is obliged to cover his genitals. although at other times even when alone. Unless he needs to be naked like bathing, defecating, and having a rest (Az-Zuhaili, 2010). 
Since childhood, a child should be accustomed to close aurat even though for example a girl is not closed, all like adult women. With this habituation, a child has been implanted to have an embarrassed attitude. When later the child grows up will be accustomed to covering the aurat according to the provisions of the Shari'a. Even they will feel embarrassed if their genitals are seen by others, especially those who are not mahram.

\subsubsection{Signs of Baligh}

In Safinah an-Najah, it is stated that there are three signs of baligh (adult), namely: reach the age of 15 th for men and women, ihtilah (wet dreams) for men and women at the age of 9 years, and menstruation for women at 9 years old (Salim al-Hadrami, 2009). Adults referred to in this chapter (chapter) are not as intended in psychology, but a Muslim who has been subjected to the obligation to practice the Shari'ah and stay away from what is prohibited (mukallaf).

Knowledge about the signs of baligh should be given to children before they experience it. Because besides reaching the age of 15 years, Ibtilam and menstruation cannot be planned when they will experience it. So, by being taught before they experience, when they experience it they already know what happened and carry out their obligations.

In today's terms baligh is similar to puberty experienced by someone. When a child experiences puberty, change will occur to him from physical change and psychological changes. In this time the child begins to have interest in the opposite sex. In addition, at puberty the impulse to lust in children is so great that the association between the opposite sex need to be limited to religious norms.
Therefore, it is important for children to be given knowledge of the social boundaries allowed by the Shari'a. Education is not only provided by schools, but family roles are also needed. In addition, the community can play a role in social control, so that when there is an association that exceed the limit, it can immediately reprimand it. Because one reason for the occurrence of promiscuity in adolescent is the careless of the community to the free association that occurs around it.

\subsubsection{Menstruation, Childbirth}

Attention of ulama pesantren (kyai) to sexual education for women. In the book Risalah al-Mabidh written using Javanese Pegon language, Kyai Masruhan Ihsan clorified about menstruation, childbirth and other one's that were generally experienced by women. This indicates that Islamic attention to sexual health is so detailed not only the obligations of the Shari'a. Starting from when a woman experiences menstruation, the difference in blood menstruation with istihadhah, the time limit for menstruation, is related to childbirth (nifas) and wiladah.

Associated with the beginning of a woman experiencing menstruation in the classic book, there is no difference with the classic books (kitab) of other jurisprudence, namely after the age of 9 years or 9 th years less 14 days. Whether menstruation comes out before even 9th years of age, it is not considered menstruation.

The minimum menstruation time limit is overnight without stopping or if counted overnight if 
there is a pause in menstruation bleeding. whether it is less than overnight the blood is not punished by menstrual blood but the blood is stable. The maximum period of menstruation is 15 days, even though there is a pause. If it has exceeded 15 days, it still bleeds, the rest is considered as istihadah blood.

Knowledge about menstruation, childbirth, and wiladah does not only have implication for the reproductive health of a woman, but also related to the obligations of the Sharia. A woman who is experiencing menstruation, childbirth, or wiladab is not subject to the obligation to carry out several pillars of Islam such as prayer and fasting. After the period has stopped, a woman is obliged to jinabah bathe (obligatory bathe) with some harmony (intention and wash the whole body with water). Unlike the prayer that is left when experiencing menstruation and childbirth that does not need to be replaced at another time, fasting must be replaced at another time with the number of days according to what was left behind.

\subsection{The Second Part}

\subsubsection{Marriage as an Effort to Maintain the Existence of Religion}

The existence of religion is very dependent on human existence. There is no human being, then religion is gone. Because it has become something that religion should discuss about reproduction, paying more attention to other things. whether juxtaposed with the Islam religion, reproduction is equal in position to da'wah in Islam.
The one that interesting in the Qurratul Uyun of the classic book (kitab) is before discussing about how to do husband and wife relations well, preceded by a discussion about marriage. In this case, marriage is an absolute condition for a Muslim to develop offspring. Without marriage, the relationship between men and women is called adultery, which is a big sin. With marriage ties in the Qur'an referred to as mitsaqan ghalizha (solid agreement), the nasab of a child who is born becomes clear or recognised.

Among the virtues of marriage which are explained in the Qurrotul Uyun book (kitab Qurratul Uyun), this is to save sight, maintain farji (genitals), expect better offspring, cleanse the heart, and strengthen the determination to worship. When someone is married someone will have a partner to share in everything, especially in worship and kindness.

In Islam nasab (lineage) is very important. Nasab here is not only a biological father but also a biological father in marriage. Even when the Prophet raised Zaid bin Harithah and pinned his name to become Zaid bin Muhammad. But after that the word of God came down:

\section{"Call them (adopted children) with (using) the names of their fathers." (QS. Al- Ahzab: 5}

So, after that, his name returned to Zaid bin Harithah, and omitted Muhammad's name because he was not the biological father of Zaid. That's where the importance of someone in the Islamic view, so the bond of marriage becomes very important in life. This is what distinguish sexual education in Islam and the West. whether in the West 
the purpose of sexual education is to prevent pregnancy and venereal disease, in Islam it prevents from act of adultery (free sex) which will result in nasab discontinuation.

Besides relating to this matter, in several Figh books (kitab) which are often used as a reference for Islamic boarding schools discussed about marriage conditions, pillars of marriage, divorce, and matters relating to marriage. With the provisions of the Shari'a that are so strict it does not mean that Islam makes it difficult for his people to do marriages. Especially when it comes to the various divorce if it is not known they could have mentally and mentally infected their wives.

\subsubsection{The Provisions (adab-adab) in intercourse}

After the marriage, the desire to have offspring is the main thing for married couples, so they try it with an intimate relationship (intercourse) both of them. But in Islam, especially in the treasures of Islamic jurisprudence (Fiqh Pesantren) in conducting intimate relations between husband and wife cannot be done carelessly. There are provisions (adab) that must be considered. These provisions not only have implications for prohibitions or recommendations that bringable sin or reward, but on the quality of the offspring that will be born.

The classic Book (kitab) of Qurrotul Uyun explains clearly the times which are performed during intimate relations. Thus, there are days/dates that should be avoided to do so. The days that need to be avoided are Wednesday at the end of the month, the third, fifth, thirteenth, sixteenth, twenty-one, twenty-four, and twenty-five in each month (al-Tihami).
Besides that, provision in conducting intimate relationship is very much considered in the treasures of Islamic boarding school (Pesantren). Starting from how to start, things to avoid, prayers when you want to start and after it's finished. When you want to start it is recommended by author of classic book (kitab) that a husband should clean his heart and decorate himself with repentance from all sins and mistakes that have been made, then start in a holy state, start doing sunnab things by putting your right foot first, then saying "Bismillahi wassalamu ala Rasulillah assalamu alaikum", and perform sunnah prayers 2 rak'ah (twice) or more.

After this is done, it is recommended that a husband read the selected of verse above the crown of his wife as guards for all enemies. A husband is also encouraged to ask the goodness of his wife to Allah SWT so that it is kept away from ugliness and other prayers that can keep the family in harmony. These prayers are not only recommended when they want to have intimate relationships, but in the morning and evening so that family life is given happiness all of time.

\subsubsection{Psychological Relationship between Husbands and Wives}

In addition to discussing the intimate relationship between husband and wife, the Islamic jurisprudence (Fiqh Pesantren) also explain the psychological relationship between husband and wife in the family sphere. Shaikh Nawawi alBantani in his classic book (kitab) Uqudul al-Lujain Fi Bayani Huququ al-Zaujain explained how the tasks of the husband and the obligations of the wife in family.

Among the obligations of a husband according to Shaikh Nawawi is to associate well (busn al-ashrah), provide 
income (mu'ab), dowry (dowry), and teach about obligatory and sunnah worship issues including menstrual issues and wife's obligation to obey against the husband as long as not in the matter of immorality. Whereas the wife's obligation includes obedience to the husband as long as it is not in the matter of immorality, good relations, surrendering his body to the husband, staying at home, guarding himself from infidelity with other men, taking the veil so that he is not seen as a face or palm hands, do not demand anything that is beyond the ability of the husband, keep the husband from using illicit asset and honest in menstrual matter.

Some contemporary scientists consider that Sheikh Nawawi in his classic book (kitab) is too leaning towards a husband following a patriarchal culture. And the space to move as a wife is very limited to try to minimize socializing in the public space. This is certainly without reason, because the influence of social life in the Grand Mosque at that time as the place of Sheikh Nawawi settled. Different if social life in Indonesia gives freedom to socialize to a woman in public space.

In this globalization era, the roles of men and women in the public sphere already have the same opportunities both work and other activities. Moreover, the increasing economic needs to meet daily needs require a wife to work. This does not mean Shaikh Nawawi's thinking about the obligations of a wife which limit her role in the public sphere. See this context, which is the pressure point of the obligation is to avoid infidelity and protect yourself from the views of other men.

\section{Conclusion}

The attention of boarding schools to sexual education is undoubtedly, see the treasur of Islamic boarding school (Pesantren) that discuss a lot about the theme. Besides the classic books (kitab) that are directly themed about sexual education, there are also classic book (kitab) that indirectly discuss them. Sexual education in Islamic jurisprudence (Fiqh Pesantren) is divided into two parts, namely sexual education from childhood to adulthood and sexual education in marriage relationships.

In the first part, it was discussed about being purify, closing the genitals, signs of baligh, as well as those related to women's Fiqh such as menstruation, childbirth, and wiladah. Such knowledge is very important for someone in order to live this life, especially worshiping Allah SW'T as the obligation of a servant. In the second part discussed from the marriage, the importance of marriage, the provisions do intercourse, to build a harmonious psychological relationship between husband and wife. From the explanation, marriage covers all aspects of life, not just about intercourse orientation.

\section{References}

Abdul Moqsit Ghozali (2002), Tubuh, Seksualitas, dan Kedaulatan Perempuan; Bunga Rampai Pemikiran Ulama Muda, Yogyakarta: Rahima.

Ahmad Nurcholish, et al. (2016), Seksualitas \& Agama: Kesehatan Reproduksi dalam Perspektif AgamaAgama, Jakarta: PT. Elex Media Komputindo.

Aksin Wijaya (2016), Sejarah Kenabian dalam Perspektif Tafsir Nuzuli 
Mubammad Izzat Darwazah, Bandung: PT. Mizan Pustaka.

Alya Andika (2010), Bicara Seks Bersama Anak, Yogyakarta: Galangpress.

KH. MA. Sahal Mahfudh (2011), Nuansa Figh Sosial, cet. VII, Yogyakarta: LkiS.

Laurie Bechhofer, dkk., (2012) "National Sexuality Education Standards: Core Content and Skills K12,"Journal of School Health, http://www.futureofsexeducaton. org/documents/josh-fosestandards-web.pdf . Hal. 9-10, America.

Leafio Rinta, (2015), "Pendidikan Seksual dalam Membentuk Perilaku Seksual Positif Pada Remaja dan Implikasinya Terhadap Ketahanan Psikologi Remaja," Jurnal Ketahanan Nasional, vol.21, no.3, Hal. 169, Yogyakarta.

Martin van Bruinessen (2015), Kitab Kuning, Pesantren, dan Tarekat, cet. 2, Yogyakarta: Gading Publishing.

Masruhan Ihsan (Tanpa Tahun), Risalah al-Mabid, Tanpa Tempat.

Mestika Zed (2003), Metode Penelitian Kepustakaan, Jakarta: Yayasan Obor Indonesia.

Muhammad al-Tihami al-Idrisi alHusaini (Tanpa Tahun), Qurratul Uyun Bisyarbi Nadzmi Ibni Yamun, Beirut: Dar Ibn Hazm.

Muhammad Bin Qasim al-Ghazi (2016), Syarh Fath al-Qarib al-Mujib Abu Syuja', Kediri: Zamzam.

Nawawi al-Bantani, Uqudul Lujain fi Bayani Huquq az-Zaujain, Surabaya: Dar al-'Ilm.

Nicole Haberland and Deborah Rogow (2015), "Sexuality Education:
Emerging Trends in Evidence and Practice," Journal of Adolescenth Health, Vol.56, Hal.18, Amsterdam.

Niken Widi Astuti dan Noeratri Andanwerti (2016), "Penerapan Pendidikan Seksual oleh Guru dan Orang Tua Bagi Remaja Berkebutuhan Khusus," Jurnal Psikologi Pendidikan, Vol. 10, No. 2, Hal.17, Yogyakarta.

Nur Mahmudah (2015), Memotret Wajah Pendidikan Seksualitas di Pesantren, Jurnal Quality, Vol. 3, hal. 133-157, Kudus.

Rijal Mumazziq Z (2015), "Peta Pemikiran Figh di Kalangan Pesantren", Jurnal Al-Abwal, Vol. 7, Hal. 63-85, Jember.

S. Nasution (2012), Metode Research (Penelitian Ilmiah), Jakarta: Bumi Aksara.

Salim bin Samir al-Hadrami (2009), Matan Safinah an-Najah Fi Ma Yajibu 'ala al-'Abdi li Maulah, Beirut: Darul Minhaj.

Salmi Ahmad Sudan (2015), "Educating Children on Sexual Matters Based on the Teaching of Islam: The Role of Muslim Parents," Journal of Education and Social Policy, vol.2, no. 5, hal. 113, USA.

Thoha Hamim (2004), Islam \& NU di Bawah Tekanan Problematika Kontemporer, Surabaya: Diantama.

Wahbah Az-Zuhaili (2010), Figh Islam Wa Adillatuhu, Jilid 1, terj. Abdul Hayyie al-Kattani, Jakarta: Gema Insani.

Wina Sanjaya (2013), Penelitian Pendidikan :Jenis, Metode, dan Prosedur, Jakarta: Kencana Prenada Media Grup.

Zamakhsyari Dhofier (2015), Tradisi Pesantren: Studi Pandangan Hidup Kyai

Cite this as:

Mufid, Herlina. Sexual Education in Khazanah Fiqh Pesantren (Islamic Jurisprudence).

Islamic Insights Journal. 2019: Vol. 01(1): PP 47-58. 
Islamic Insights Journal; Volume 01 Number 01, May 2019, pp. 47-58

dan Visinya Mengenai Masa Depan

Indonesia, cet. Ke 9, Jakarta: LP3ES.

Cite this as:

Mufid, Herlina. Sexual Education in Khazanah Fiqh Pesantren (Islamic Jurisprudence).

Islamic Insights Journal. 2019: Vol. 01(1): PP 47-58. 